\title{
Speech behavior of bilingual primary school children in a multinational region
}

\author{
Nonna N. Murovanaya ${ }^{1 *}$, Yulia Y. Kurbangalieva ${ }^{1}$, Tatiana N. Korenyakina ${ }^{2}$, Bella V. \\ Rykova $^{3}$, and Nailya I. Abdullaeva ${ }^{3}$ \\ ${ }^{1}$ Sevastopol State University, Humanitarian Pedagogical Institute, Department of Preschool, Primary \\ and Special Education, Sevastopol, Russia \\ ${ }^{2}$ Astrakhan State University, Department of Preschool and Primary Education, Astrakhan, Russia \\ ${ }^{3}$ Znamensk Branch of Astrakhan State University, Chair of Pedagogics, Psychology \& Humanitarian \\ Disciplines, Znamensk, Russia
}

\begin{abstract}
Historically, the Russian language has become a common means of communication in the Russian Federation. The Republic of Crimea is a place where the population is represented by a multinational community. At that, some areas are densely populated with a single nation, where children speak the Tatar language, that is, are essentially everyday bilinguals. The most characteristic type of bilingualism in Russia is the national Russian language, which is learned both through training and direct communication with the Russian-speaking population. Early everyday bilingualism is common when the assimilation of the native and Russian languages develops almost in parallel. The authors have received new information on the peculiarities of the acquisition of Russian and native Tatar languages in primary school children raised in a multilingual environment. It is proved that speech therapy examination of speech disorders in bilingual children should be conducted in two languages. The article presents developed recommendations for teaching bilingual children in a Russian-language school, depending on the degree of proficiency in Russian and the presence of speech disorders.
\end{abstract}

Keywords: speech, language, bilingualism, multiculturalism, speech pathology.

\section{Introduction}

There are few places left on the globe where the population speaks only their native language, mainly because of the mass media, and especially television, penetrating everywhere, transmitting flows of foreign-language information. Most people travel, migrate, try to adapt to a new environment. As is known, foreign languages, and often several of them, are included in the minimum school curricula in many countries. Often, the language of education in a particular country differs from the pupils' native language.

Bilingualism is of particular interest for speech therapy, since it often causes a specific kind of speech mistakes in the Russian language due to both the peculiarities of the

* Corresponding author: nonna.murovanaya@gmail.com 
interaction of language systems and the violation of speech and mental development. The factor of bilingualism for children with speech pathology is burdensome, which cannot but affect the development of speech, cognitive, and, consequently, educational activities [1-5].

The relevance of the present study is due to the existing contradictions between the need for practice in an adequate assessment of the speech status in bilingual children at primary school, and the lack of appropriate theoretically grounded research and correction methods of speech pathology.

\section{Results and discussion}

The study was conducted in educational institutions of Nakhimov (North Side), Balaklava (Baydarskaya Valley) districts of the city of Sevastopol, where a single-ethnic population (Crimean Tatars) lives densely. The study covered 160 children of primary school age from Tatar families and mixed families. All children were trained in Russian-language educational institutions. According to the background, all the children studied were brought up in a bilingual environment. Communication in the family usually was in two languages (Russian and Tatar), with some exceptions.

All children had normal psychomotor development in early childhood. Taking into account the factor of bilingualism, the study was conducted in Russian and Tatar. This was dictated by the need for an adequate assessment of speech development in children. The speech was evaluated in the course of speech therapy research, during observations of children in the game and subject activity situations, as well as communication in the family.

A comprehensive speech therapy study and analysis of the results obtained, has allowed identifying monolingual and bilingual children. Bilingual Tatar children had different levels of the Russian language proficiency, which were further conditionally designated as good, medium, and low.

Logopedic study of children from Tatar families, who spoke Russian at home and school (65 children out of 160), has shown that the Russian language proficiency was conditionally consistent with the age-appropriate normal level, i.e., was identified as a good level of the Russian language proficiency. The children in the family communicated in Russian and Tatar, while at school - in Russian. The analysis has shown that the process of the formation of the subject correlation of words in children has been completed, and the basic generalizing concepts have been formed, as well as the ability to designate them with the corresponding lexical units. The children spoke the Tatar language just as fluently.

The children basically mastered the entire complex system of practical grammar in both languages: the productive forms of inflection and word formation were assimilated and systematized, and the unproductive forms of inflection were at the final stage of differentiation. The syntactic structure of the phrases and sentence constructions corresponded to the generally accepted rules of use. The analysis of the lexical and grammatical aspect of speech indicated the formedness of a vocal-act model in the minds of children, whose main operations were the selection and compatibility of lexical units, as well as the determination of the correctness of the utterance relative to the language standard, which ensured the improvement of language ability and the development of a sense of language in this group children.

The analysis of phonetics-phonology perception has revealed the formedness of this speech aspect. The children pronounced all the sounds of their native and Russian languages. They distinguished the sonance and voicelessness, hardness and softness of consonant sounds of the Russian and Tatar languages.

Almost all children, when speaking the Tatar language had nonpermanent word inflection mistakes: prefixes and suffixes were added, as well as prepositions were inserted into the phrase, followed by the endings of Russian words. 
Speech development features of children of this group could be considered indicators of ontogenetic patterns of speech development of Tatar bilingual children when both language systems were assimilated quite harmoniously.

Among observed children, 60 of them spoke both languages in their families, and mostly Russian at school. The Russian language proficiency was classified as intermediate and was characterized by certain general features. A study of articulatory motor skills has shown that the movements of the tongue were slightly limited due to increased tension of tongue muscles. This tension especially affected the muscles of the tongue root. The tip of the tongue was not sufficiently pronounced and did not perform the movements that were necessary for the production of vibrant sounds. These children were diagnosed with dysarthria. The level of the Russian language proficiency was classified as conditionally average.

The lack of sound pronunciation skill was expressed variatively.

Most of the children had features of sound pronunciation in Russian, which were due to the influence of their native Tatar language. On the one hand, this was expressed by the absence of softening in words where consonants were softened in Russian words ("sem' sem", "bol'shoi - boloshoi", "morkov' - morokov"). On the other hand, children softened consonants where there was no softening in Russian words: "prishol - pirishol", "sidel sidel", "pomil-pamil"".

Children had difficulty learning the consonant blend in pronunciation and inserted a vowel between them ("dver' - dever'", "park - paryk", etc.), because the Tatar language lacks the words with consonant blend. Many children did not master specific Russian sounds, such as [ts], [ch], since there are no such sounds in the Tatar language. Children were replacing them with Tatar sounds [shch], and [s] ("cherepakha - shcherepakha", "chasishchasi", "contsert-kanaserat", "tsvet-savet" etc.).

A certain limited everyday vocabulary was noted, as well as an inaccurate use of some words, intermittent mistakes in grammatical structuring, and difficulties in updating the dictionary. The mixing of words was carried out based on the similarity of functional meaning, as well as the replacement of generalizing concepts with words of specific meaning.

In the course of the study, various manifestations of agrammatism were revealed in children of this group when using unproductive forms of inflection and word formation.

The influence of the Russian language on the native Tatar language was less pronounced.

The study of the development level of the Tatar language has shown that phrasal speech was quite structured grammatically, although the phrases were short (two-three words), there were many stereotypical expressions; monologue speech in both Russian and native was poorly developed.

Mistakes of phonetic, phonemic, semantic, and agrammatic nature were also noted when analyzing the children's writing.

Speech therapy analysis has allowed qualifying the children's phonetic and phonemic speech underdevelopment. The study of the speech (in Russian and Tatar) of children from this group has shown a significant similarity of oral speech disorders in both language systems.

The study has revealed that 35 children communicated at home in Tatar, while at school - in Russian. Their Russian language proficiency was classified as low and was characterized by the following general features: children mixed Russian and Tatar languages in the names of subjects; there was interference (they started a phrase in one language and ended it in another); along with the mixing of Russian and Tatar languages at the lexical level, they mixed grammatical structuring; the structure of a phrase pronounced in Russian, obeyed the rules of grammatical structuring in Tatar. The sound-pronouncing aspect of the speech was characterized by mixings, distortions, and omissions of sounds (whistling and hissing sigmatism, rotacism, and lambdacism). Thus, the level of the Russian language proficiency was classified as low. 
The limitation of the volume of active and passive vocabulary, difficulties in updating nouns, adjectives, and verbs were revealed as well. Generalizing concepts and the ability to designate them with the appropriate lexical unit were not formed. Multiple verb substitutions reflected the children's inability to distinguish essential signs of actions and differentiate shades of meaning.

When analyzing the grammatical aspect of speech, pronounced agrammatism was revealed. It was dominated by a mixture of the tenses of verbs, nouns, and other parts of speech. The children lacked the sense of analogy, and they had difficulty in actualizing verbs.

The most characteristic mistakes of inflection were omissions, substitutions, and confusion of inflections of adjectives formed according to standard and nonstandard models, the predominant substitution of plural forms with singular forms, as well as the use of nonexistent inflections.

The analysis of phonemic perception has shown that the children of this subgroup did not differentiate phonemes that were oppositional in terms of sonance and voicelessness, hardness and softness.

When analyzing the sound-pronouncing aspect of speech, a large number of substitutions and mixes of sounds was noted. The same sound had several substitutes; therefore, the sound pronunciation of the same word was different.

All the children of the group under consideration were making mistakes in the design of words with a complex syllabic structure. At that, all types of mistakes were noted, namely omissions, substitutions, permutations, perseverations, and comparisons. The pronunciation of words of varying complexity in isolated and contextual use cases was distorted.

The children of this group were characterized by attention instability and distraction.

They memorized speech material worse, and performed tasks related to active language activities with a large number of mistakes.

Conducted speech therapy analysis has allowed classifying these children as having general speech underdevelopment of the $3^{\text {rd }}$ level (Table 1).

The lack of formedness of all aspects of speech not only affected the limited understanding and difficulties in forming statements in the native language but also created obstacles to mastering the language as a system, and even more so to mastering a second language.

Table 1. Distribution of children into groups depending on their knowledge of the native Tatar language and the level of the Russian language proficiency.

\begin{tabular}{|c|c|c|c|}
\hline Groups & $\begin{array}{c}\text { Number of } \\
\text { children }\end{array}$ & The Tatar language & The Russian language \\
\hline $1^{\text {st }}$ group & 65 & $\begin{array}{c}\text { Good level of the Tatar } \\
\text { language proficiency }\end{array}$ & $\begin{array}{c}\text { Good level of the Russian } \\
\text { language proficiency }\end{array}$ \\
\hline $2^{\text {nd }}$ group & 60 & $\begin{array}{c}\text { Phonetic and phonemic speech } \\
\text { underdevelopment }\end{array}$ & $\begin{array}{c}\text { Phonetic and phonemic speech } \\
\text { underdevelopment }\end{array}$ \\
\hline $3^{\text {rd }}$ group & 35 & $\begin{array}{c}\text { General speech } \\
\text { underdevelopment of the 3rd } \\
\text { level }\end{array}$ & $\begin{array}{c}\text { General speech } \\
\text { underdevelopment of the 3rd } \\
\text { level }\end{array}$ \\
\hline
\end{tabular}

The conducted study has shown that everyday (natural) bilingualism is characterized by complex relationships between the two language systems, revealed in some primary school children. To diagnose the speech development level and speech pathology, it is necessary to study speech in both native and second language. This allows giving differentiated recommendations on the organization and content of pedagogical work with bilingual children when studying in a Russian-language school. 


\section{Main work areas}

Younger schoolchildren with a good level of knowledge of the Russian language (1st group), while studying at a Russian school, need clarification of the phonemic perception of the phonemes of the Russian language, the sound appearance of Russian words (especially with a confluence of consonants). To this end, it is necessary to focus the active attention of children on the awareness of the difference in the phonetics of the Russian and Tatar languages. In the absence of such special classes, children in this group have difficulties in writing, reading, and mathematics.

For children with phonetic-phonemic and general speech underdevelopment (2nd and 3rd groups), it is necessary to organize speech therapy classes in the Tatar language (and, accordingly, develop a methodology), since the psychophysiological and neuropsychological mechanisms of speech in these children are developed better in the dominant (native) language. After successful correctional work in the Tatar language, such children can continue their education in Russian.

Speech therapy assistance to children with speech disorders should be aimed at correcting the language system in which the child communicates in the family. This is because the compilation of the motor program of speech planning and the selection of articulatory movements, as well as the implementation of the motor program are provided by the code of speech movements, which means that a special neuromotor mechanism and its stereotypes are formed at the early stages of the child's speech development according to the sound system of the native language [6-8].

\section{Conclusion}

The present study does not completely solve the problem of bilingualism. The prospects of the present study are related to the further development of speech therapy methods to study and correct speech in the Tatar language, the further development of diagnostic criteria for speech in the Tatar language, as well as the development of special methods for teaching Russian to Tatar children with speech pathology.

\section{References}

1. E.A. Babaeva, Gotovnost' k obucheniyu v shkole detey-bilingvov s rechevoy patologiyey [Readiness to study at school for bilingual children with speech pathology]. Dissertation of the candidate of pedagogical sciences (Moscow State Pedagogical University, Moscow, 1992)

2. S.S. Bakshikhanova, Analiz mekhanizmov recheproizvodstva kak psikholingvisticheskaya osnova diagnostiki rechevykh defektov v usloviyakh buryatsko-russkogo bilingvizma [Analysis of the mechanisms of speech production as a psycholinguistic basis for the diagnosis of speech defects in the conditions of BuryatRussian bilingualism]. Dissertation of the candidate of psychological sciences (Irkutsk State Pedagogical University, Irkutsk, 1999)

3. L.I. Belyakova, M.M. Osipovskaya, Nekotoryye psikholingvisticheskiye osobennosti svyaznoy rechi zaikayushchikhsya shkol'nikov [Some psycholinguistic features of coherent speech of stuttering schoolchildren], in Nauchnyye trudy Moskovskogo Pedagogicheskogo Gosudarstvennogo Universiteta Psikhologo-pedagogicheskaya seriya [Scientific works of the Moscow State Pedagogical University Psychological and pedagogical series] (Prometey, Moscow, 2002) 
4. E.O. Golikova, O.B. Inshakova, Osobennosti formirovaniya leksiki u detey-bilingvov [Features of the formation of vocabulary in bilingual children], in Proceedings of the 14th Mezhdunarodnyy Simpozium po Psikholingvistike i Teorii Kommunikatsii. Yazykovoye soznaniye: ustoyavsheyesya i spornoye [14th International Symposium on Psycholinguistics and Communication Theory. Linguistic consciousness: wellestablished and controversial], 29-31 May 2003, Moscow, Russia (2003)

5. S.B. Fayed, Kharakteristika rechevogo razvitiya arabskikh detey, postupayushchikh v shkolu [Characteristics of the speech development of Arab children entering school] (Moscow State Pedagogical University, Moscow, 2002)

6. N.I. Abdullaeva, Problema sotsializatsii v vospitanii detey v raznykh kul'turakh [The problem of socialization in raising children in different cultures], in Proceedings of the 2nd interregional seminar "Gosudarstvennaya sotsial'naya politika po zashchite detstva: teoriya i praktika" ["State social policy for the protection of children: theory and practice"], 117-120 (Izdatelstvo AIPKP, Astrakhan, 2007)

7. T.N. Korenyakina, Formirovaniye obshcheuchebnykh umeniy [Formation of general educational skills] (LAP LAMBERT Academic Publishing Germany, Saarbrücken, 2011)

8. Yu.Yu. Kurbangalieva, Korrektsionno-razvivayushchaya rabota s det'mi s bilingvizmom [Correctional and developmental work with children with bilingualism] (Publisher Sorokin Roman Vasilyevich, Astrakhan, 2018) 